\title{
Description About Materials Mathematics the Special Needs of Junior School of Result National Examination 2019
}

\author{
Sri Wuryanti*, Rahmi Rivalina, Dian Rahdiani, Handaru Catu Bagus, Wenny Saraswaty \\ Center for Assessment and Learning of the Research and Development Agency \\ Ministry of Education and Culture \\ Jakarta, Indonesia \\ *Sriwuryanti03@gmail.com
}

\begin{abstract}
The purpose of this study was to see students with special needs in inclusive schools and their absorption of mathematics subject matter in the 2018/2019 Junior High School National Examination. Although the National Examination has been legally abolished, the results of the last National Examination 2018/2019 can still be used to capture students' minimum academic abilities and also for reflection to improve the quality of education better. The ability of students can be seen from the results of the national exam, while the absorption of mathematics can be seen from the proportion of students with special needs in inclusive schools who can correctly answer questions on the National Mathematics Exam. The population of this study was all junior high school students who took the National Examination for the 2018/2019 academic year, while the sample was all students with special needs who added 3806 junior high school students who took the National Examination for the 2018/2019 academic year. The data used is secondary data, namely the Junior High School National Examination data for the 2018/2019 academic year. Data analysis using Excel software, and then carried out descriptive statistical analysis. The results showed that the highest score of the National Mathematics Examination for students with special needs in inclusive schools was material and opportunity statistics with a score of 52.74, while the lowest score was in the coverage of numerical material with a score of 34.53. For, the next material coverage is Algebra 46.84, and Geometry and measurement 38.10. The range of values for participants with special needs is very large so it needs assistance to improve the abilities of students. The weakness of students with special needs in inclusive schools in Mathematics is the scope of the numerical material.
\end{abstract}

Keywords-National Examination, grades, absorption, children with special needs, Junior High School

\section{INTRODUCTION}

According to Handayani [1] that the essence of inclusive education consists of two things, namely: i) Inclusive education is the incorporation of regular education and special education into one school system that is unified to meet the different needs of all students; ii) Inclusive education is not just a method or approach to education, but a form of implementation of a philosophy that recognizes the diversity of people who have a single mission to build a better life together.

In connection with this essence, the objectives of inclusive education as stated in Permendiknas RI No.70 of 2009 are [2]: (i) to provide the widest possible opportunity for all students who have physical, emotional, mental, and socio-cultural barriers or have potential intelligence. and/or special talents to obtain quality education according to their needs and abilities; (ii) realizing education provision that respects diversity and is not discriminatory for all participants. This is by the "Salamanca Statement" and "Framework for Action on Special Needs Education", in article 7 that: "The fundamental principle of inclusive schools is that, wherever possible, all children should learn together regardless of their difficulties or differences. However, inclusive schools must view and respond to the different needs of their students. " It is increasingly important to place students as subjects with attention to the different needs of each child [3]

Evaluation of learning in inclusive schools according to Puspito [4] is in learning evaluation, as stated in Permendiknas No. 70 of 2009 articles 7 to 9 [2]; (1) The assessment of learning outcomes for inclusive education students shall refer to the type of curriculum at the level of the education unit concerned. (2) Students who take learning based on a curriculum developed by national education standards or above national education are obliged to follow the national test. (3) Students who have disabilities and follow learning based on a curriculum developed under the education standard take an exam administered by the education unit concerned. (4) Students who complete and graduate by the national education standards receive a diploma which is issued by the government. (5) Students who have disabilities who complete education based on a curriculum developed by an education unit under the national education standard receive a Certificate of Completion of Study, whose postcard is issued by the education unit concerned. (6) Students who receive a Graduate Study can continue their education at a higher level or level in an education unit that provides inclusive education or a special education unit. 
Meanwhile, students with special needs who carry out their education in inclusive schools can take the National Examination which is held jointly by the central government at the junior and senior high school levels to get a diploma. Meanwhile, there were 3086 students with special needs at the last National Examination or 2018/2019 at the junior high school level, which consisted of various kinds of specialties. It seems that students with special needs who took part in the UN at that time proved that children with special needs had high enthusiasm to develop themselves and optimize their potential. In addition to the appreciation of the number of students with special needs who participated in the UN assessment and evaluation, it was seen from the results of the tests that the students passed. Subjects that are followed by inclusive students are the same as children their age. Namely, Mathematics, Natural Sciences, Indonesian, and English. This study only describes the acquisition of the Mathematics test results for the scope and the absorption capacity for the material. Is his enthusiasm also directly proportional to the results of existing mathematical absorption? The average achievement of children of his age from all over Indonesia is 46.54 in the low category, while for students with special needs the average achievement is 43.90 . This means that the average of the results of this assessment is still below the average.

The most fundamental problem that arises from this research is that the average ability of the national exam results for students with special needs is still below the existing competency standards. Several factors influence the relationship so that the value is still below the expected performance standard. Because the existing data is the absorption of student assessment results, what we can describe is to describe some of the assessed knowledge that comes from the updated Bloom theory, the assessment grid that is expected to be achieved in the evaluation of educational assessments, as well as several test items that are possibly the most difficult among the others. Even though the National Examination has been frozen, for now, the concepts of mathematics material are still needed to improve learning in educational units.

The most fundamental problem that arises from this research is that the average ability of the national exam results for students with special needs is still below the existing competency standards. Several factors influence the relationship so that the value is still below the expected performance standard. Because the existing data is the absorption of student assessment results, what we can describe is to describe some of the assessed knowledge that comes from the updated Bloom theory, the assessment grid that is expected to be achieved in the evaluation of educational assessments, as well as several test items that are possibly the most difficult among the others. Even though the National Examination has been frozen, for now, the concepts of mathematics material are still needed to improve learning in educational units.

\section{METHODS}

The population of this research is students with special needs in public schools or not in special schools. Meanwhile, the data analysis used is in the form of quantitative descriptive data in the form of secondary document data consisting of a collection of data in the form of graphs, and a table of students' attainment in the National Examination for the 2019/2020 Academic Year which has been processed in the Excel application program. Meanwhile, qualitative analysis is used to interpret and describe several things related to existing data.

\section{LITERATURE REVIEW}

The quality of human resources is a national asset that is very important for the progress of a country. A country with quality human resources will determine the progress and prosperity of the country itself. Quality human resources can be obtained through education. Education is a planned effort so that students can actively develop their potential so that they have spiritual strength, intelligence, skills, noble character, and character. Therefore, efforts to improve the quality of education must be made to improve the quality of Indonesian human resources who are ready and able to compete with other countries.

The government as an institution that is responsible for the implementation of education in Indonesia plays a very important role and must be able to carry out and facilitate the implementation of quality education. The government is expected to meet the needs needed by schools so that the learning process in schools can run optimally. Monitoring the quality of education must be carried out periodically and systematically. This was done to find more comprehensive information on the problems faced and to answer questions that often arise in connection with the low quality of education in Indonesia.

According to the results of a study conducted by Santoso [5], the low quality of education is caused by low learning achievement, the difficulty of students in understanding and mastering subject matter, the inability to think critically and to apply the knowledge gained in school in different situations. Teachers as educators have a very big responsibility in developing or improving the competence of students optimally. Teachers who have high material mastery competence are expected to be able to teach all subject matter to students thoroughly and optimally to achieve learning objectives. The success of the teacher in presenting subject matter and the extent to which students have absorbed the subject matter cannot be separated from preparation, mastery of subject matter, and the use of appropriate teaching methods.

The definition of learning outcomes cannot be separated from what happens in learning activities both at school and outside of school. Bloom states that learning outcomes include three domains [6]: (1) cognitive domain, the focus of this domain is on the ability to think, remember, and solve problems; (2) effective domain, related to values, attitudes, interests, and appreciation; and (3) psychomotor domain, related to motor skills and arranging. Thus it can be said that the learning outcomes can be in the form of a product, such as certain knowledge, attitudes, and skills. The learning 
experience of students can be influenced by several factors such as the quality of the interaction between students, material, and teachers, as well as the characteristics of students when they get learning. Meanwhile, Bridge, Judd, and Mocck [7] stated that learning outcomes are a production function of the education system. School quality is a function of an effective learning process, leadership, teacher participation, student participation, management, organization, physical environment and resources, school customer satisfaction, input and facilities support, and school culture. The optimization of each of these components determines the quality of the school as an education delivery unit

Students with special needs who attend formal schools, including human resources, must be facilitated so that these students can attend lessons at school like other students. Schools must be able to facilitate inclusive students. This was reinforced in the 1993 Exam Nation resolution on inclusive education and the Minister of Education Regulation Number 70 of 2009 on inclusive education [2]. Herawati [8] emphasizes that all physical, intellectual, social, emotional, and linguistic disorders, children with disabilities, talents, street children, child laborers, children in remote or migratory communities, children from speaking ethnic groups ethnic/ cultural minorities, and children vulnerable to marginalization have the right to education without discrimination .

Inclusive education in Indonesia, according to Karsidi [9] The development of science and technology in the field of education with special needs students finds a lot of new evidence that $A B K$ with various physical and/or intellectual barriers, can attend education in regular schools after teachers and other resources at school, curriculum, and learning is specially designed, allowing each individual to get services that suit their individual needs. Findings of this kind make it clear that an inclusive paradigm can overcome barriers to education for children with special needs, and at the same time emphasize that a segregative approach is not the only solution in meeting needs and overcoming educational barriers for children with special needs.

Bloom's Cognitive Level according to Susanto [10] between $\mathrm{C} 1$ Knowledge, at this level emphasizes the ability to recall material that has been learned, such as knowledge of terms, special facts, conventions, trends, and sequences, classifications, and categories, criteria, and methodology. C2 comprehension, understanding is defined as the ability to understand certain material being studied. These abilities are (i) Translation (ability to change symbols from one form to another), (ii) Interpretation (ability to explain material), (iii) Extrapolation (ability to expand meaning). At this level, students answer questions in their own words and by providing examples of both principles and concepts. C3 Application, the application is defined as the ability to apply information to real situations, where students can apply their understanding by using it in real terms. C4 Analysis is the ability to describe a material into clearer components. This capability can be in the form of (i) Analysis of elements, (ii) Analysis of relationships, (iii) Analysis of organizing principles of organization. At this level, students are asked to break down information into several sections, find assumptions, and distinguish opinions and facts and find causal relationships. C5 Synthesis, at defined as the ability to produce and combine elements to form a unique structure. This capability can take the form of producing unique communications, intact plans or activities, and abstract relationships. At this level, students are required to produce their hypotheses or theories by combining various sciences and knowledge. C6 Evaluation, at defined as the ability to assess the benefits of something for a specific purpose based on clear criteria. This activity deals with the value of an idea, creation, method, or method.

Mathematics lessons according to Huda [11] is a subject that has a fairly large role in human life, especially in the world of education so that mathematics is a subject that is taught from elementary school to college level to help students have the ability to solve problems with critical, careful, effective, and efficient. It is stated that there are five basic mathematical abilities which are standard, namely problem solving, reasoning and evidence, communication, connection representation. By referring to the five NCTM ability standards above, the mathematics learning objectives set out in the 2006 Curriculum issued by the Ministry of National Education essentially include (1) connections between concepts in mathematics and their use in solving problems, (2) reasoning, (3) problem solving, (4) communication and representation, and (5) effective factors.

According to Wiersma and Jurs [12], measurement is a numerical assessment of the facts to be measured according to certain criteria, while according to Allen and Yen [13], measurement is defined as the determination of numbers in a systematic way to express individual circumstances. Thus, the essence of measurement is determining figures about individual facts or circumstances to be measured according to certain rules. In other words, measurement is a broader concept than a test.

One of the measuring tools used to obtain this competency information is a learning achievement test. According to Crocker and Algina [14], testing is a standard process for obtaining a sample of behavior from a particular domain. Suke Silverius [15] says that the learning outcome test is a series of questions that must be answered or a task that must be done by students and the results are used to measure student learning progress. Anastasi [16] states that a learning outcome test or learning achievement test is a test that measures the knowledge a person has due to an educational program or a training program. Cronbach [17] defines testing as a systematic procedure for observing the behavior of learners and describing them with the help of a numerical or categorical scale.

In daily life at school, teachers still find it difficult to make a good measuring instrument (test). This can be seen from the results of research conducted by Kartowagiran and Jaidun [18] and Hari Setiadi [19] which state that teachers still do not understand and need guidance in conducting assessments. 
According to Umar, et al [20], the terms of a good test include (1) valid, that is, each measuring instrument only measures one dimension or aspect, and (2) reliability (reliability) of the measuring instrument. Reliability in this case includes the accuracy/accuracy of measurement results. The accuracy of the measurement results is determined by the amount of accurate and reliable information. Meanwhile, the characteristics of the items include the power of difference, the function of the answer choices, and the difficulty level of the items.

According to Suryabrata [21], the steps that must be taken to obtain a standardized test instrument are: (1) developing test specifications or grids, (2) writing questions, (3) reviewing and revising questions, (4) testing regularly. empirical, and (5) administering the test for standardization purposes. The test instruments used in the exam have gone through a standard or standard process, meaning that the items have been calibrated and are on the same scale so that the scores or scores obtained by students can be compared between provinces, between cities/districts, and between schools.

Charles et al. [22] stated that the level of problem difficulty was measured by the number of test-takers who answered the questions correctly, and was measured by the number of testtakers who answered incorrectly, while Suryabrata [21] said that the difficulty level of the items was a proportion. subjects who answered that question correctly. The level of difficulty index is located from 0 to 1 , the greater or closer to one proportion of subjects who answered correctly the easier the question. For example, the difficulty level of the items was 0.87 , meaning that $87 \%$ of the subjects answered correctly and the absorption of the subject matter tested was $87 \%$.

The Ministry of Education and Culture [23] classified the UN results into five categories, namely: (1) Very Good (A) (average UN score > 7.50), (2) Good (B) - (6.50 < average UN score $\leq 7.50)$, (3) Moderate (C) $-(5.50<$ average UN score $\leq$
6.50), (4) Poor (D) - (4.50<average average UN score $\leq 5.50)$, and (5) Very less (E) - (average UN score $\leq 4.50)$.

\section{RESULTS}

The dimensions measured in the national exam consist of a material scope and cognitive level. The scope of material includes (1) cognitive (2) comprehension (3) application (4) analysis (5) Evaluation and (6) Evaluation). The cognitive level is divided into knowledge (knowing), application (applying), and reasoning (reasoning). The percentage distribution of material scope and cognitive level is presented in Table 1

TABLE I. Distribution of Percentage of MAterial Scope AND COGNITIVE LEVEL

\begin{tabular}{|l|l|l|l|}
\hline \multicolumn{1}{|c|}{ Scope of material } & Percent & \multicolumn{1}{|c|}{ Cognitive level } & Percent \\
\hline Algebra & $50 \%$ & Knowledge, understanding & $26 \%$ \\
\hline Calculus & $7.5 \%$ & Aplication & $34 \%$ \\
\hline Geometry and Trigonometry & $17.5 \%$ & Reasoning & $40 \%$ \\
\hline Statistic & $25 \%$ & & \\
\hline
\end{tabular}

In Table 1, it can be seen that the scope of material for Algebra is $50 \%$, higher than the scope of other material. This is related to the breadth of the material. Meanwhile, the cognitive level of reasoning has the highest proportion of the three measured cognitive levels. The proportion of test items at the level of knowledge and understanding was lower than the application and reasoning abilities, namely 26\%, 34\% application, and $40 \%$ reasoning (analysis, synthesis, and evaluation). Meanwhile, the scope of material in the test items included algebra $50 \%$, calculus $7.5 \%$, geometry and trigonometry $17.5 \%$, and $25 \%$ statistics. Everything, tailored to the needs of each student according to their specialty. There are forms of material that use braille, large writing for low-vision children, some are written exams, and even for students who do not experience physical barriers using computers is the same as other students. The distribution of the number of questions for each scope of material and material tested can be seen in Table 2 .

TABLE II.

DisTRIBUTION OF THE NUMBER OF QUESTIONS AND MATERIALS TESTED IN THE NATIONAL LANGUAGE EXAM INDONESIA

\begin{tabular}{|c|c|c|}
\hline Scope and material & Item test total & Material of exam \\
\hline Algebra & 20 & $\begin{array}{l}\text { 1. Forms of Power, Root, and Logarithm } \\
\text { 2. Function, Function Composition, Function Inversion, and Function Graph } \\
\text { 3. Quadratic Equations and Functions } \\
\text { 4. Systems of Equations and Linear Inequality Systems } \\
\text { 5. Linear Program } \\
\text { 6. Matrix } \\
\text { 7. Arithmetic and Geometry Sequences and Series }\end{array}$ \\
\hline Calculus & 6 & $\begin{array}{l}\text { 1. Limit } \\
\text { 2. Derivatives } \\
\text { 3. Integral }\end{array}$ \\
\hline Geometry and Trigonometry & 4 & $\begin{array}{l}\text { 1. Comparison of trigonometry } \\
\text { 2. Trigonometric functions and their graphs } \\
\text { 3. Rules of sines and cosines } \\
\text { 4. Position and distance from points, lines, and planes } \\
\text { 5. The angle between the line and the plane, and between the two planes } \\
\text { 6. Equations of circles and tangents to circles } \\
\text { 7. Geometry transformations }\end{array}$ \\
\hline Statistic and probability & 10 & $\begin{array}{l}\text { 1. Presentation of data in the form of tables, diagrams, and graphs } \\
\text { 2. Size of the data center, location, and distribution } \\
\text { 3. Enumeration rules } \\
\text { 4. Probability }\end{array}$ \\
\hline
\end{tabular}


In the table 3, the average results of the 2018/2019 inclusion students' national exam scores will be presented as seen from the absorption of the results of absorption.

TABLE III. ThE AVERAGE RESUlTS OF THE 2018/2019 INCLUSION STUDENTS' NATIONAL

\begin{tabular}{|l|l|l|}
\hline Amount & \multicolumn{1}{|c|}{ Scope and Material } & Average Score \\
\hline 3806 & Algebra & 34.53 \\
\cline { 2 - 3 } & Calculus & 46.84 \\
\cline { 2 - 3 } & Geometry and Trigonometry & 38.10 \\
\cline { 2 - 3 } & Statistic and Probability & 57.74 \\
\hline
\end{tabular}

In figure 1 , the average results of the 2018/2019 inclusion students' national exam scores will be presented in terms of absorption. The average score of achievement of the highest assessment result is Statistic and Probability with an average return score of 57.74, while the result is the lowers and maybe students have difficulty with the material is Algebra on the score 34.53 .

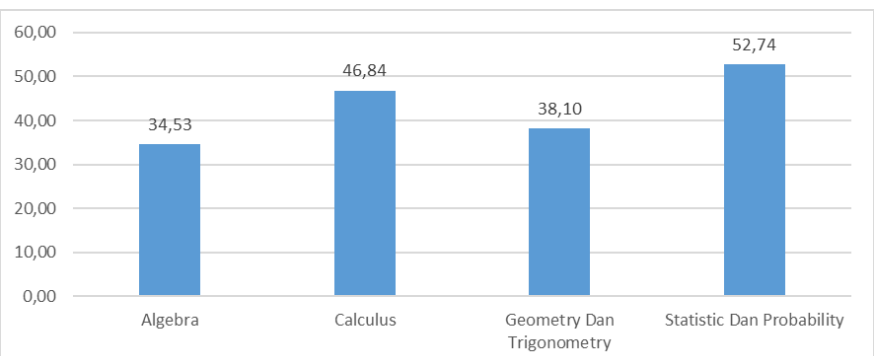

Fig. 1. The average results of the 2018/2019 inclusion students' national exam.

Next in the next presentation, examples of questions that were quite difficult for students with special needs were shown in the latest national exams which were published on the Ministry of Education and Culture's website, including:

\section{A. Item Test algebra number 1}

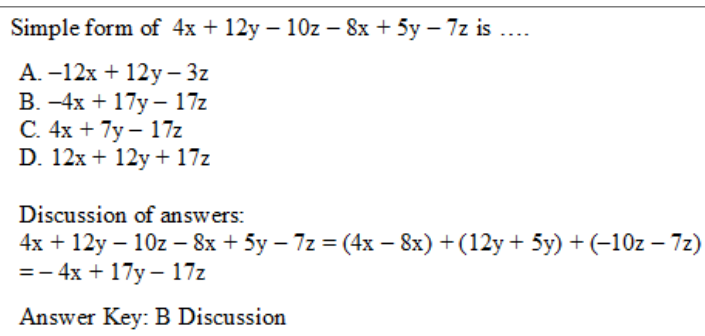

This problem examines addition and subtraction in Algebra, and, is used to be done in learning. However, students with special needs still experience significant difficulties. Teachers, need to help students in solving these algebraic concepts to make it easier, maybe with more concrete learning methods or models. Because students with visual impairments must maximize their familiarity, for other students it is necessary with other media. Teachers need to maximize the potential that still exists in students.

\section{B. Item Test Algebra Number 1}

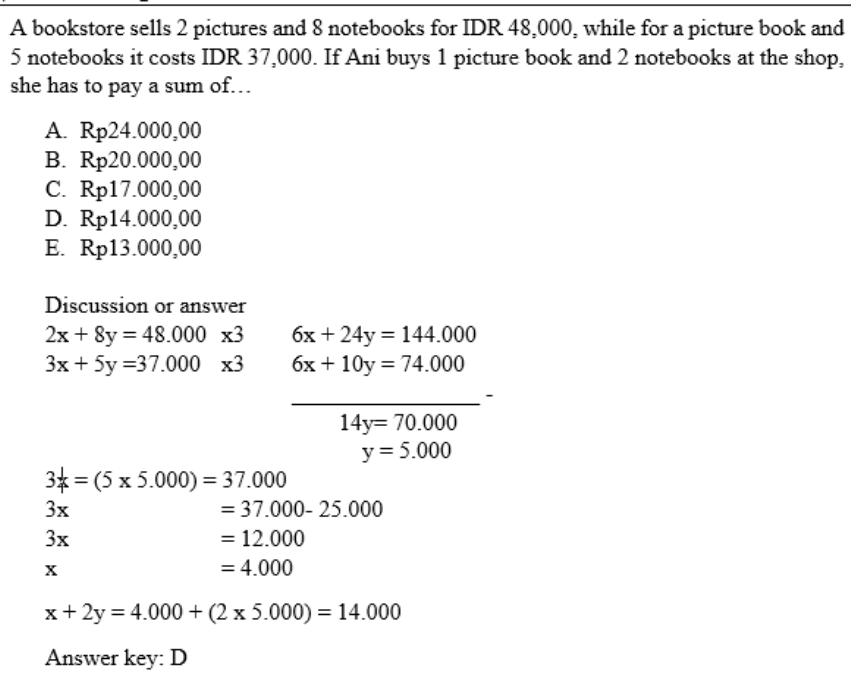

This story-shaped problem is common in classroom learning. To finish it, students simply apply procedures that are often used in learning. However, it may be quite difficult for children with special needs to answer some questions with a model like this. Therefore, it is necessary to practice basic algebra and repeatedly to understand it and also the right learning method to make it easier for students with special needs with very unique characters.

\section{CONCLUSION}

The score results from the 2018/2019 national exam for mathematics subjects are unique because the test item with a low average score is algebra. Which is the basis of science itself, algebraic material is material that unites from all coverage of other mathematical material. The notion of algebra itself is a branch of mathematics that studies simplification and problem solving using symbols that are substitutes for constants or variables. It is necessary, serious training to understand the concept and solve problems of algebra material itself, students need intense assistance with the right methods, media, and approaches. Even though the national exam has been frozen, the ability to solve basic math problems such as the example questions above is still very below the minimum competence. For students who do not have special needs, it is also very difficult for them to complete numeric or mathematical test items. Moreover, for students with special needs, whose physical or mental barriers are very influential. However, the enthusiasm of inclusive students needs to be appreciated, as well as their courage to go to school with the same curriculum as students their age.

\section{ACKNOWLEDGMENT}

We Said many thanks to Mr. Bagus which inspires a lot for his writing is very coherent and easy to understand even though in English. All fellow researchers and engineers Pusmenjar 
Center. Ms. Asrijanty, Ms. Rahmawati, Ms. Mira, Mr. Santi and Mr. Lilis female lead in the office.

\section{REFERENCES}

[1] T. Handayani and A. S. Rahadian, "Peraturan perundangan dan implementasi pendidikan inklusif," Masy. Indones., vol. 39, no. 1, p. 149701, 2013.

[2] "Peraturan Menteri Pendidikan Nasional Republik Indonesia Nomor 70 Tahun 2009 tentang Pendidikan Inklusif Bagi Peserta Didik Yang Memiliki Kelainan Dan Memiliki Potensi Kecerdasan Dan/Atau Bakat Istimewa." .

[3] UNESCO, No Title. 1999.

[4] Peni Puspito, "Kebijakan Pendidikan Inklusif di Indonesia," 2012. http://pepenk26.blogspot.com/2015/02/kebijakan-pendidikan-inklusidi.html.

[5] G. A. Santoso, Studi Perkembangan Kognitif Siswa SD. Jakarta: Lembaga Penelitian Universitas Indonesia, 2000.

[6] Benjamin S Bloom, Taxonomy of Educational Objectives. New York: D Mckay Company Inc, 1971.

[7] R. G. Bridge, C. M. Judd, and P. R. Moock, The determinants of educational outcomes. Massachusets: Ballinger Publishing Company.

[8] N. I. Herawati, "Pendidikan Inklusif," EduHumaniora| J. Pendidik. Dasar Kampus Cibiru, vol. 2, no. 1, 2016.

[9] Ravik Karsidi, "Ilmu Pendidikan Dan Paradigma Pendidikan Inklusif Yang Berkualitas,” 2015. https://www.uny.ac.id/fokus-kita/prof-drravik-karsidi-ms.

[10] R. U. Susanto, "Ranah Kognitif dalam Dunia Evaluasi Pembelajaran: dari C1 hingga C6," 2019. https://duta.co/ranah-kognitif-dalam-duniaevaluasi-pembelajaran-dari-c1-hingga-c6.
[11] M. Huda, "Investigating factors influencing mathematics teaching performance: an empirical study," Int. J. Instr., vol. 11, no. 3, pp. 391402, 2018.

[12] W. Wiersma and S. G. Jurs, Educational Measurement and Testing. Boston: Allyn and Bacon, 1990.

[13] M. J. Allen and W. M. Yen, Introduction Measurement Theory. California: Monterey, 1979.

[14] L. Crocker and J. Algina, Introduction to classical and modern test theory. ERIC, 1986.

[15] S. Suke, "Evaluasi Hasil Belajar dan Umpan Balik," Jakarta Gramedia Widia Sarana Indones., 1991.

[16] A. Anastasi and S. Urbina, Psychological testing. Prentice Hall/Pearson Education, 1997.

[17] L. J. Cronbach, "Essentials of psychological testing.," 1949.

[18] B. Kartowagiran and A. Jaedun, "Model asesmen autentik untuk menilai hasil belajar siswa sekolah menengah pertama (SMP): Implementasi asesmen autentik di SMP," J. Penelit. dan Eval. Pendidik., vol. 20, no. 2, pp. 131-141, 2016.

[19] H. Setiadi, "Pelaksanaan penilaian pada Kurikulum 2013," J. Penelit. dan Eval. Pendidik., vol. 20, no. 2, pp. 166-178, 2016.

[20] Umar, Jahja, and B. Hayat, Efektifitas Pengujian Soal Bentuk Soal Pilihan Ganda dan Benar Salah. Jakarta: Pusat Pengujian, 2000.

[21] S. Suryabrata, Pengembangan Tes Hasil Belajar. Jakarta: Rajawali, 1987.

[22] C. D. Hopkins and R. L. Antes, "Classroom testing: Construction. Itasca, IL.” FE Peacock Publishers, Inc, 1979.

[23] Departemen Pendidikan dan Kebudayaan, Buku Panduan Pemanfaatan Hasil UN. Jakarta: Pusat Pengujian, 2012. 